\title{
THE VASCULAR FLORA OF A SECTION OF THE TRANSFORMED PIWONIA RIVER CHANNEL - THE SURROUNDING DITCH ON LAKE BIKCZE (LECZNA-WŁODAWA LAKELAND) - IN RELATION TO HABITAT CONDITIONS
}

\author{
Magdalena Pogorzelec, Artur Serafin \\ Department of General Ecology, University of Life Sciences in Lublin, \\ Akademicka 13, 20-950 Lublin \\ magdalena.pogorzelec@up.lublin.pl; artur.serafin@up.lublin.pl
}

Received: 5.02 .2010

\begin{abstract}
In the period 2007-2009, floristic, habitat and physico-chemical analysis was made of the hydraulically improved surrounding ditch of Lake Bikcze in the Łęczna-Włodawa Lakeland. Hemicryptophytes, with a large proportion of geophytes as well as hydrophytes and helophytes, were the main component of the flora of the studied section of the transformed Piwonia River channel. In terms of historical-geographical classification, spontaneophytes were predominant, and apophytes among them, whereas anthropophytes were poorly represented, which was confirmed by the correspondingly high values of the synanthropization and apophytization indices (> 50\%) as well as the low value of the anthropophytization index (approx. 2\%). In the aspect of the range of occurrence, Euro-Siberian and cosmopolitan species were predominant, which are classified in terms of the indicator values as hygrophilous plants, neutral to continentality, living in moderately cool or moderately warm climatic conditions, characterized by a wide range of tolerance to the trophic state index and to soil acidity. An analysis of the values of the basic physico-chemical factors of the stagnant water in the surrounding ditch showed variations in the value of $\mathrm{pH}$, electrolytic conductivity and the value of the concentration of organic and ammonium nitrogen as well as of organic phosphorus and phosphates. In spite of the anthropogenic nature of the studied watercourse, the qualitative and quantitative proportions of the flora species indicated the natural state of the flora based on the native vegetation, characteristic of the study area.
\end{abstract}

Key words: vascular flora, surrounding ditch, Piwonia River, Łęczna-Włodawa Lakeland

\section{INTRODUCTION}

The water relations of the Łęczna-Włodawa Lakeland, shaping the nature of ecological changes in both terrestrial and aquatic ecosystems, are very susceptible to anthropogenic transformations ( $\mathrm{F} \mathrm{i} \mathrm{j} \mathrm{a} 1$ k ow ski, 1975; Wilg a t, 1991).

Land drainage projects, in the form of riverbed regulation, digging drainage ditches or the inclusion of lakes in the runoff network, implemented already from the middle of the 19th century, were designed to prevent the formation of riparian wetlands and waterlogged areas which persisted as a result of small terrain depressions and shallow lying impermeable deposits. At the same time, however, they contributed to the deepening of summer deficits, caused by low rainfall levels and the low water retention capacity of the substrate (Harasimiuk and Wojtanowicz, 1998).

The construction of the drainage system of the Wieprz-Krzna Canal (1954-1961) and subsequently its operation entailed significant changes in the ecological structure of the whole macroregion. It was designed to regulate the annual water cycle and to ensure rational management in the Łęczna-Włodawa Lakeland, leading to economic revival and transformations of this one of the most deprived areas of Poland (M i c h a lczyk and Turczyński, 1998; Turczyński et al. 2000).

As part of the expansion of the Wieprz-Krzna Canal drainage system, a part of the lakes of the Lakeland, including Lake Bikcze, was transformed into flood storage reservoirs.

In connection with hydraulic improvements carried out in 1969, Lake Bikcze was diked and surrounded by a drainage ditch with its outlet on the north side to the deepened Piwonia River channel. On the south, the lake was connected via a feeding canal with the neighbouring Lake Uściwierz - through a pumping 
station with the Wieprz-Krzna Canal. The high dike embankments allow the water in the lake to be dammed above its natural level, and the surrounding ditch is used for collecting and discharging water seeping through the embankments, but to date the lake has not been filled above the intermediate level (Wojcie chowski, 1976; Harasimiuk et al. 1998; Serafin and Czernaś, 2009).

The disturbances in the species composition of the flora of the originally natural plant communities, associated with the capture of nutrients of agricultural origin by the surrounding ditch in operation, are an effect of the changes in the water relations of the Lake Bikcze catchment. This condition directly affected the development of a unique plant community system, subjected to continuous synanthropization, and indirectly resulted in the impoverishment, in terms of trophy, of the active transitional bog on the western and southwestern side of the catchment (Wojciechowski et al. 1988).

The aim of the present study was to analyse the flora of the surrounding ditch of Lake Bikcze in relation to the physico-chemical conditions of its waters, taking into account the values of the basic anthropogenic indicators of the changes in the flora.

\section{MATERIALS AND METHODS}

Lake Bikcze is situated in the south-eastern part of the Łęczna-Włodawa Lakeland, which is a physiographic sub-unit of the Polesie Podlaskie macroregion. In Poland's administrative division, it is located in the centre of the Lubelskie Voivodeship (province) in Ludwin Gmina (municipality) and it is a part of the Łęczna Lakeland Landscape Park.

Lake Bikcze is classified as a shallow water body with a maximum depth of $3.3 \mathrm{~m}$, polymictic, pond-type, and in terms of trophy - it is a eutrophic lake. It usually represents water quality of class II, whereas in terms of susceptibility to degradation - class III (The report on the condition of the environment of the Lubelskie Voivodeship, 2008).

In the land use structure of this water body's catchment, natural forms classified as meadows and pastures are predominant (F u rtak et al. 1998). On the west, the shore of the lake borders on an active transitional bog evolving towards a raised bog (W o j c i e chowski, 1976; Pogorzelec and Banach, 2008; L o re n s et al. 1998). In the remaining part of the catchment, natural land uses are accompanied by agricultural land with an area of $18.14 \mathrm{ha}(\mathrm{F} \mathrm{u} \mathrm{r} \mathrm{ta} \mathrm{k}$ et al. 1998).

The present study was conducted in the period 2007-2009. The study site was a section of the transformed Piwona River, with a length of about 1,700 m, functioning as the surrounding ditch of Lake Bikcze (Figs 1, 2).

The field investigations involved making species inventories of the flora inhabiting the slopes and the channel of the surrounding ditch. In successive years, the lists of species were supplemented, and the species were identified using the key of R u tk ow s k i (2001). In the years 2007-2009, measurements of $\mathrm{pH}(\mathrm{pH}$; using a field $\mathrm{pH}$-meter) and water electrolytic conductivity $\left(\mu \mathrm{SJ} . \times \mathrm{cm}^{-1}\right.$; using a field conductometer) were also made, as well as water samples were collected twice (in July 2007 and 2008) for chemical analysis. The determination of the concentration of organic nitrogen and phosphorus, $\mathrm{NO}_{3}, \mathrm{NO}_{2}, \mathrm{NH}_{4}$ and $\mathrm{PO}_{4}$ was made at the Chemical Laboratory of the company "POMIAR-GIG" Przedstawiciel Głównego Instytutu Górnictwa ("POMIAR-GIG", Representative of the Central Mining Institute) in Lublin.

Office investigations involved a multifaceted botanical and ecological analysis of the flora. The study Z a r z y cki et al. (2002) was used to determine the proportions of species belonging to different ecological groups (by using the relevant indices for the following factors: continentality, thermal conditions, light, moisture, acidity, trophic state, organic matter content and soil granulometric composition), lifeforms as well as the number of stands and dynamic trends in the flora. The species were assigned to the historical-geographical groups and range groups; the flora synanthropization index as well as the flora apophytization and anthropophytization indices were also determined according to Chmiel (1993a; 1993b; following J a c k o w i a k, 1990). Botanical nomenclature followed M i re k et al. (2002).

\section{RESULTS}

In the period 2007-2009, a total of 107 vascular plant species was identified on the slopes and in the channel of the studied section of the Piwonia River (Table 1). The species commonly found in Poland made up the largest group $(78.5 \%$ of all identified species). The occurrence of rare species or species threatened with extinction was not found in the study area, but 3 species were distinguished for which a large reduction in the number of stands was recorded and 8 species for which the number of stands had decreased or there had been a clear loss of individuals over the last decades (Table 2).

Hemicryptophytes were predominant in the species composition of the flora; a large proportion of geophytes as well as of hydrophytes and helophytes was also observed (Table 3).

Among the species assigned to the specific historical-geographical groups, spontaneophytes (taxa 
which arrived or are native to a given area and can exist there without human intervention), were the most numerous group, and apophytes (taxa which may move from natural habitats to anthropogenic ones) predominated among them. Only two species in the flora of the investigated watercourse were classified as anthropophytes, and to be more exact - archeophytes (Table 3 ), taxa introduced or established under the influence of human activity before the year 1500: Capsella bursa-pastoris and Viola arvensis. The flora synanthropization index (showing the percentage proportion of apophytes and anthropophytes in the studied flora) was $56.4 \%$. The flora apophytization index (showing the proportion of apophytes in the flora) and the flora anthropophytization index (showing the percentage proportion of anthropophytes) had the values of $54.4 \%$ and approx. $2.0 \%$, respectively.

In the flora of the surrounding ditch on Lake Bikcze, 4 geographical (range) elements, in a strict meaning, were identified. Euro-Siberian and cosmopolitan species had the largest proportion. Circumboreal and Central European species were of lesser importance, whereas the remaining group of the species comprised overlapping elements going beyond the basic phytochoria (Table 4).

The results of the analysis of the floristic composition and of the proportions of particular species in the flora of the investigated site did not allow an exact classification of the syntaxa to be made due to the absence of characteristic combinations of species.

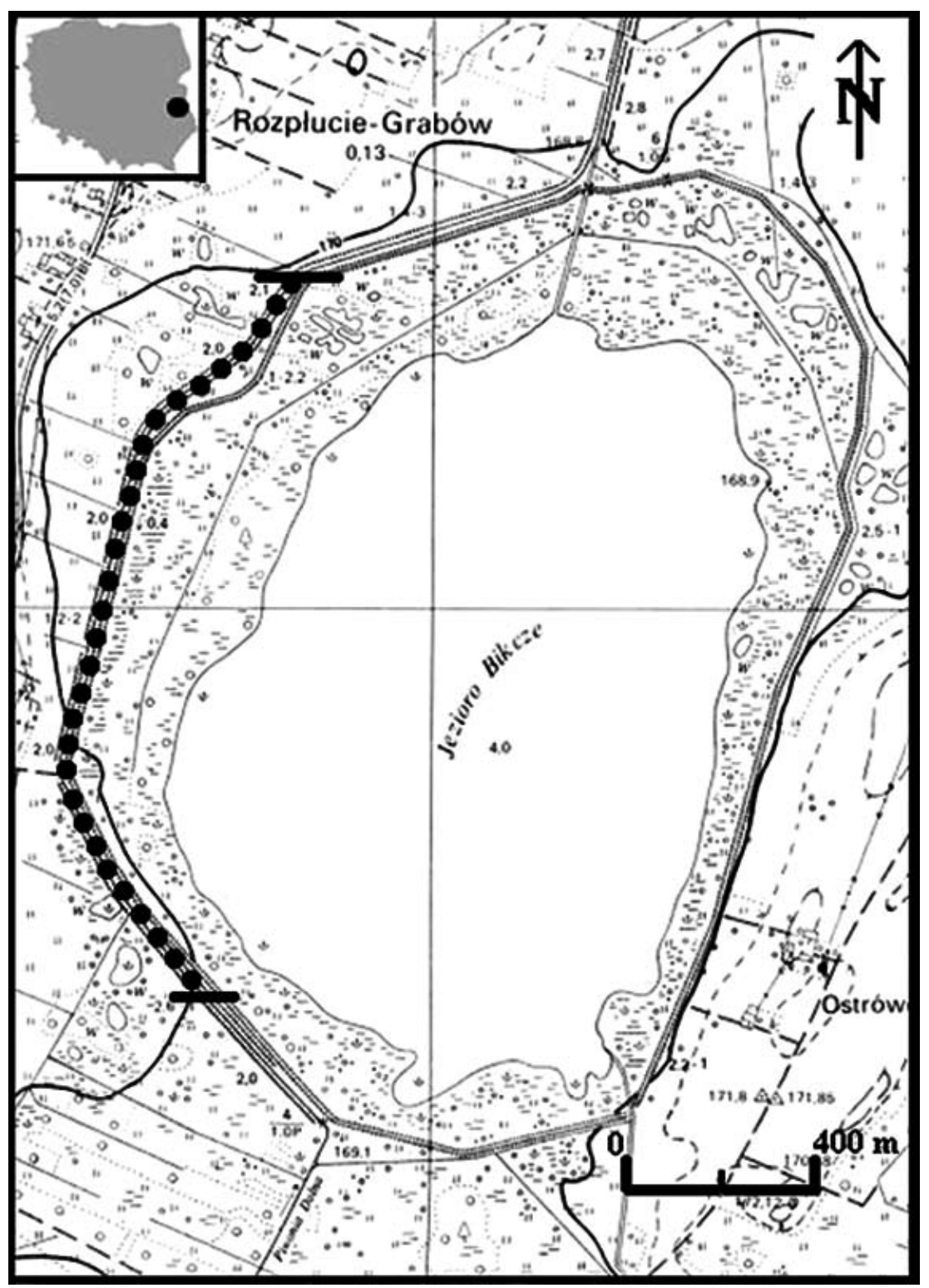

Fig. 1 Localisation of research area. 


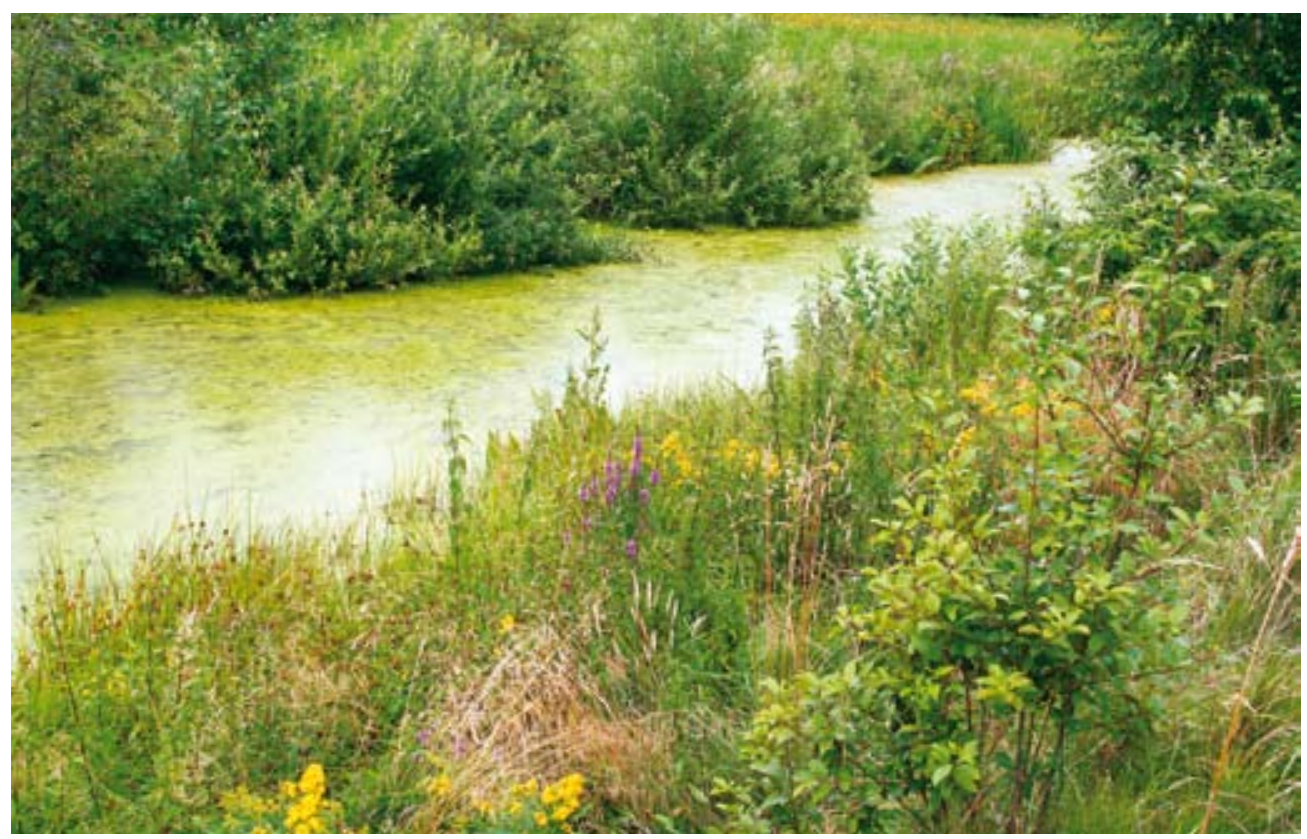

Fig. 2 Section of the transformed Piwonia River channel - the surrounding ditch on Lake Bikcze

Table 1

The species composition of the surrounding ditch on Lake Bikcze, including the assignment of species to botanical classes and families

\begin{tabular}{|c|c|}
\hline \multicolumn{2}{|c|}{ Class: Magnoliopsida } \\
\hline Families & $\begin{array}{c}\text { Species } \\
\end{array}$ \\
\hline Apiaceae & Peucedanum palustre \\
\hline \multirow{10}{*}{ Asteraceae } & Achillea millefolium \\
\hline & Artemisia vulgaris \\
\hline & Cirsium arvense \\
\hline & Cirsium palustre \\
\hline & Cirsium vulgare \\
\hline & Eupatorium cannabinum \\
\hline & Hieracium caespitosum \\
\hline & Leontodon autumnalis \\
\hline & Leontodon hispidus \\
\hline & Taraxacum officinale \\
\hline Betulaceae & Betula pendula \\
\hline Boraginaceae & Myosotis palustris \\
\hline Brassicaceae & Capsella bursa-pastoris \\
\hline \multirow{5}{*}{ Caryophyllaceae } & Lychnis flos-cuculi \\
\hline & Melandrium album \\
\hline & Stellaria graminea \\
\hline & Stellaria media \\
\hline & Stellaria palustris \\
\hline Ceratophyllaceae & Ceratophyllum demersum \\
\hline Chenopodiaceae & Cheneopodium album \\
\hline Convolvulaceae & Convolvulus arvensis \\
\hline Dipsacaceae & Knautia arvensis \\
\hline \multirow{4}{*}{ Fabaceae } & Lathyrus pratensis \\
\hline & Trifolium pratense \\
\hline & Trifolium pratense \\
\hline & Vicia cracca \\
\hline
\end{tabular}

\begin{tabular}{|c|c|}
\hline Fagaceae & Quercus petraea \\
\hline Hypericaceae & Hypericum perforatum \\
\hline \multirow{5}{*}{ Lamiaceae } & Lycopus europaeus \\
\hline & Mentha arvensis \\
\hline & Prunella vulgaris \\
\hline & Scutellaria galericuleta \\
\hline & Stachys palustris \\
\hline Lythraceae & Lythrum salicaria \\
\hline \multirow{2}{*}{ Onagraceae } & Epilobium hirsutum \\
\hline & Oenothera biennis \\
\hline \multirow{2}{*}{ Plantaginaceae } & Plantago lanceolata \\
\hline & Plantago major \\
\hline \multirow{2}{*}{ Polygonaceae } & Rumex acetosella \\
\hline & Rumex hydrolapathum \\
\hline \multirow{2}{*}{ Primulaceae } & Lysimachia nummularia \\
\hline & Lysimachia vulgaris \\
\hline \multirow{5}{*}{ Ranunculaceae } & Caltha palustris \\
\hline & Ranunculus acris \\
\hline & Ranunculus flammula \\
\hline & Ranunculus repens \\
\hline & Thalictrum flavum \\
\hline Rhamnaceae & Frangula alnus \\
\hline \multirow{9}{*}{ Rosaceae } & Comarum palustre \\
\hline & Geum rivale \\
\hline & Padus avium \\
\hline & Potentilla anserina \\
\hline & Potentilla reptans \\
\hline & Rosa canina \\
\hline & Rubus caesius \\
\hline & Rubus idaeus \\
\hline & Sorbus aucuparia \\
\hline
\end{tabular}




\begin{tabular}{|c|c|}
\hline \multirow{3}{*}{ Rubiaceae } & Galium aparine \\
\hline & Galium plaustre \\
\hline & Galium uliginosum \\
\hline \multirow{3}{*}{ Salicaceae } & Salix alba \\
\hline & Salix aurita \\
\hline & Salix cinerea \\
\hline \multirow{2}{*}{ Scrophulariaceae } & Scrophularia nadosa \\
\hline & Veronica chamaedrys \\
\hline Solanaceae & Solanum dulcamara \\
\hline Urticaceae & Urtica dioica \\
\hline Valerianaceae & Valeriana officinalis \\
\hline Violaceae & Viola arvensis \\
\hline \multicolumn{2}{|c|}{ Class: Liliopsida } \\
\hline Families & Species \\
\hline Aliaceae & Allium oleraceum \\
\hline Alismataceae & Alisma plantago-aquatica \\
\hline \multirow{7}{*}{ Cyperaceae } & Carex hirta \\
\hline & Carex nigra \\
\hline & Carex pseudocyperus \\
\hline & Carex rostrata \\
\hline & Carex vesicaria \\
\hline & Elocharis palustris \\
\hline & Scirpus sylvaticus \\
\hline Iridaceae & Iris pseudacorus \\
\hline \multirow{5}{*}{ Juncaceae } & Juncus articulatus \\
\hline & Juncus bufonius \\
\hline & Juncus conglomeratus \\
\hline & Juncus effusus \\
\hline & Juncus filiformis \\
\hline
\end{tabular}

\begin{tabular}{|c|c|}
\hline Lemnaceae & Lemna minor \\
\hline \multirow{15}{*}{ Poaceae } & Agropyron repens \\
\hline & Agrostis capillaris \\
\hline & Alopecurus pratensis \\
\hline & Dactylis glomerata \\
\hline & Deschapsia caespitosa \\
\hline & Festuca pratensis \\
\hline & Festuca rubra \\
\hline & Holcus lanatus \\
\hline & Holcus mollis \\
\hline & Lolium perenne \\
\hline & Phalaris arundinacea \\
\hline & Phleum pratense \\
\hline & Phragmites australis \\
\hline & Poa pratensis \\
\hline & Poa trivialis \\
\hline Potamogetonaceae & Potamogeton pectinatus \\
\hline Typhaceae & Typha angustifolia \\
\hline \multicolumn{2}{|c|}{ Class: Equisetopsida } \\
\hline Families & Species \\
\hline \multirow{2}{*}{ Equisetaceae } & Equisetum arvense \\
\hline & Equisetum fluviatile \\
\hline \multicolumn{2}{|c|}{ Class: Polipodiopsida } \\
\hline Families & Species \\
\hline Dryopteridaceae & Dryopteris filix-mas \\
\hline Thelypteridaceae & Thelypteris palustris \\
\hline
\end{tabular}

Table 2

The number of stands and dynamic trends for the species comprising the flora of the ditch on Lake Bikcze (according to Zarzycki et al. 2002)

\begin{tabular}{|c|c|c|c|c|c|}
\hline Rating for the number of stands (A) & $\begin{array}{l}\text { Number } \\
\text { of species }\end{array}$ & $\begin{array}{c}\text { Proportion } \\
\%\end{array}$ & Rating for dynamic trends (E) & $\begin{array}{l}\text { Number } \\
\text { of species }\end{array}$ & $\begin{array}{c}\text { Proportion } \\
\%\end{array}$ \\
\hline $\begin{array}{c}1-\text { the number of stands very small } \\
\text { (from several to a dozen or so) }\end{array}$ & 0 & 0,0 & $\begin{array}{l}-2 \text { - a large reduction in the } \\
\text { number of stands }\end{array}$ & 3 & 2,8 \\
\hline $\begin{array}{l}2-\text { a small number of stands } \\
\quad \text { (up to } 100)\end{array}$ & 0 & 0,0 & $\begin{array}{l}-1 \text { - a reduction in the number } \\
\text { of stands or a marked loss } \\
\text { of individuals in the stands }\end{array}$ & 8 & 7,5 \\
\hline $\begin{array}{l}3 \text { - a large number of stands, } \\
\text { mainly in one region }\end{array}$ & 2 & 1,9 & $\begin{array}{c}+1-\text { an increase in the number } \\
\text { of stands, a marked growth } \\
\text { in individuals in the stands }\end{array}$ & 27 & 25,2 \\
\hline $\begin{array}{l}4 \text { - a large number of stands } \\
\text { in many regions }\end{array}$ & 21 & 19,6 & $\begin{array}{l}+2-\text { a large increase and the } \\
\text { occupation of new stands }\end{array}$ & 38 & 35,5 \\
\hline 5 - common in the whole country & 84 & 78,5 & $\begin{array}{l}-/+- \text { the existing stands } \\
\text { disappear and new ones } \\
\text { appear }\end{array}$ & 5 & 4,6 \\
\hline - species of undetermined affinity & 0 & 0,0 & $\begin{array}{l}\text { - species of undefined } \\
\text { dynamic trends }\end{array}$ & 26 & 24,4 \\
\hline Total & 107 & 100,0 & Total & 107 & 100,0 \\
\hline
\end{tabular}


Table 3

The proportions of different plant life-forms and historical-geographical groups in the flora of the ditch on Lake Bikcze

\begin{tabular}{|c|c|c|c|c|c|c|c|}
\hline Life forms (f) & $\begin{array}{l}\text { Number of } \\
\text { species }\end{array}$ & $\begin{array}{c}\text { Proportion } \\
\%\end{array}$ & \multicolumn{3}{|c|}{ Historical-geographical group } & $\begin{array}{l}\text { Number of } \\
\text { species }\end{array}$ & $\begin{array}{c}\text { Proportion } \\
\%\end{array}$ \\
\hline growing to a height of over $5 \mathrm{~m}$ & 5 & 4,7 & \multirow{4}{*}{ 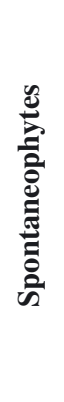 } & \multirow{2}{*}{\multicolumn{2}{|c|}{$\begin{array}{l}\text { Sp - non-synanthropic } \\
\text { spontaneophytes }\end{array}$}} & \multirow{2}{*}{44} & \multirow{2}{*}{41,1} \\
\hline $\begin{array}{l}\mathbf{N} \text { - nanophanerophytes, shrubs and small } \\
\text { trees, from } 0.5 \text { up to } 5 \mathrm{~m} \text { in height }\end{array}$ & 8 & 7,5 & & & & & \\
\hline $\begin{array}{l}\text { Ch - woody chamaephytes (buds }>25 \mathrm{~cm} \\
\text { above ground) }\end{array}$ & 0 & 0,0 & & \multirow{2}{*}{\multicolumn{2}{|c|}{ Ap - apophytes }} & \multirow{2}{*}{55} & \multirow{2}{*}{51,4} \\
\hline $\begin{array}{l}\text { C - herbaceous chamaephytes (buds }<25 \\
\mathrm{~cm} \text { above ground) }\end{array}$ & 4 & 3,7 & & & & & \\
\hline $\begin{array}{l}\text { H - hemicryptophytes (buds at ground } \\
\text { level) }\end{array}$ & 72 & 67,3 & \multirow{6}{*}{ 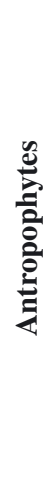 } & \multirow{4}{*}{\multicolumn{2}{|c|}{ Arch - archeophytes }} & \multirow[t]{2}{*}{2} & \multirow[t]{2}{*}{1,9} \\
\hline G - geophytes (buds in soil) & 18 & 16,8 & & & & & \\
\hline T - therophytes (annuals) & 8 & 7,5 & & & & & \\
\hline $\begin{array}{l}\text { Hy - hydrophytes and helophytes (buds } \\
\text { in water) }\end{array}$ & 15 & 14,0 & & & & 0 & 0,0 \\
\hline $\begin{array}{l}\text { li - lianas (plants rooted in soil, requiring } \\
\text { supports) }\end{array}$ & 3 & 2,8 & & \multirow{2}{*}{\multicolumn{2}{|c|}{ D - diaphytes }} & \multirow[t]{2}{*}{0} & \multirow[t]{2}{*}{0,0} \\
\hline pp - semiparasites & 0 & 0 & & & & & \\
\hline - species of undetermined affinity & 0 & 0 & - sp & cies $c$ & f undetermined affinity & 6 & 5,6 \\
\hline Total & 107 & 124,3 & & & Total & 107 & 100,0 \\
\hline
\end{tabular}

Table 4

The proportions of geographical (range) elements in the flora of the surrounding ditch on Lake Bikcze

(CB - circumboreal; ES - Euro-Siberian; E - Central European;

sOZ - sub-Atlantic; P - Pontian-Pannonian; ZAS - Central Asiatic; M - Mediterranean;

IT - Irano-Turanian; AM - American; KOSM - cosmopolitan)

\begin{tabular}{|c|c|c|c|c|c|c|c|}
\hline & 己ิ & 氠 & 되 & $\Xi$ & $\sum$ & 是 & 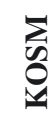 \\
\hline CB & 10 & & & & & & \\
\hline ES & & 28 & & 1 & 2 & & \\
\hline $\mathbf{E}$ & & & 6 & & & & \\
\hline sOZ & & & 1 & & & & \\
\hline $\mathbf{M}$ & 5 & 8 & 6 & & & & \\
\hline M-E & & & & 3 & 1 & & \\
\hline M-ES & & & & 3 & & 2 & \\
\hline $\mathbf{P}$ & & & & 1 & & & \\
\hline KOSM & & & & & & & 24 \\
\hline
\end{tabular}


The analysis performed based on the indicator values ( $\mathrm{Zarzycki}$ et al. 2002), describing the preferences of species, allowed us to find that moistureloving plants (characteristic of both fresh soils and moist wet soils, but also typical of aquatic environments) were the main component of the flora of the investigated section of the watercourse. In the species composition of the flora, species neutral to continentality, preferring moderately cool and moderately warm climatic conditions, were represented in greatest numbers. The plant species inhabiting the surrounding ditch, through their specific preferences, indicated the occurrence of nutrient-rich soil/water (eutrophic) and moderately nutrient-poor soil/water (mesotrophic) in the habitat; however, more than a half of the species was characterized by a wide range of ecological tolerance to this factor. It was similar in the case of soil acidity. But the largest group of species indicated neutral soils with a $\mathrm{pH}$ of 6.0-7.0. According to the analysis of the organic matter content level and the soil granulometric composition, there was found a predominance of species preferring sandy clays and silty deposits $(90.6 \%$ of species) as well as mineral/humic soils (at the same time, with a large proportion of species having a narrow range of ecological tolerance; Table 5).

The in situ measurements of abiotic factors of the environment, conducted at different dates in the period 2007-2009, showed variations in the value of $\mathrm{pH}$ (from 6.68 to 7.82 ) and electrolytic conductivity (344-418 $\left.\mu \mathrm{S} \times \mathrm{cm}^{-1}\right)$ of the stagnant water in the surrounding ditch. The values of the concentration of organic and ammonium nitrogen as well as of organic phosphorus and phosphates distinctly changed during the study. No presence of nitrite ions was found in the water (Table 6).

Table 5

The percentage proportions of plant species with different habitat requirements in the flora of the studied section of the surrounding ditch (calculated using the ecological indicator values, Zarzycki et al. 2002)

\begin{tabular}{|c|c|c|c|c|c|c|c|}
\hline \multirow{2}{*}{ Choosen indicators } & \multicolumn{6}{|c|}{ Ecological indicator values } & \multirow{2}{*}{ Stenobionts } \\
\hline & 1 & 2 & 3 & 4 & 5 & 6 & \\
\hline $\mathrm{L}$ - light value & 0,0 & 2,8 & 15,9 & 75,7 & 26,2 & 0,0 & 91,6 \\
\hline $\mathrm{T}$ - temperature value & 2,8 & 21,5 & 88,8 & 100,0 & 8,1 & 0,0 & 7,5 \\
\hline $\mathrm{K}$ - continentality value & 0,0 & 0,9 & 100,0 & 0,9 & 0,0 & 0,0 & 98,1 \\
\hline $\mathrm{W}$ - soil moisture value & 0,0 & 13,1 & 46,7 & 52,3 & 33,6 & 7,5 & 48,6 \\
\hline $\mathrm{Tr}$ - trophy value & 0,0 & 7,5 & 55,1 & 78,5 & 8,4 & 0,0 & 54,2 \\
\hline $\mathrm{R}$ - soil (water) acidity $(\mathrm{pH})$ value & 0,0 & 6,5 & 29,0 & 87,8 & 38,3 & 0,0 & 50,5 \\
\hline $\mathrm{H}$ - organic matter content value & 6,5 & 72,9 & 44,0 & 0,0 & 0,0 & 0,0 & 73,8 \\
\hline D - soil granulometric value & 0,9 & 6,5 & 32,7 & 90,6 & 39,2 & 0,0 & 44,0 \\
\hline
\end{tabular}

Table 6

The values of the studied abiotic factors of the environment in the water of the surrounding ditch, in the period 2007-2009 (maximum values are marked in black, minimum values in grey)

\begin{tabular}{|c|c|c|c|c|c|c|c|c|}
\hline \multirow{3}{*}{ Date } & \multicolumn{8}{|c|}{ Studied abiotic factors } \\
\hline & \multirow{2}{*}{$\begin{array}{l}\text { Conductivity }(\mu \mathrm{S} \\
\left.\mathrm{cm}^{-1}\right)\end{array}$} & \multirow{2}{*}{$\begin{array}{l}\text { Acidity } \\
(\mathrm{pH})\end{array}$} & $\mathrm{N}$ org & $\mathrm{NO}_{3}$ & $\mathrm{NO}_{2}$ & $\mathrm{NH}_{4}$ & P org. & $\mathrm{PO}_{4}$ \\
\hline & & & \multicolumn{6}{|c|}{$\left(\mathrm{mg} \cdot \mathrm{dm}^{-3}\right)$} \\
\hline 02.07 .2007 & 401,0 & 7,50 & - & - & - & - & - & - \\
\hline 09.07.2007 & 398,0 & 7,75 & - & - & - & - & - & - \\
\hline 16.07 .2007 & 405,0 & 7,82 & - & - & - & - & - & - \\
\hline 19.07.2007 & 344,0 & 6,73 & 5,57 & 0,23 & 0 & 0,50 & 0,69 & 0,19 \\
\hline 03.07 .2008 & 418,0 & 7,44 & - & - & - & - & - & - \\
\hline 14.07.2008 & 398,0 & 7,36 & - & - & - & - & - & - \\
\hline 26.07.2008 & 377,0 & 6,68 & 3,84 & 0,20 & 0 & 1,24 & 1,41 & 0,50 \\
\hline 16.05.2009 & 376,0 & 7,29 & - & - & - & - & - & - \\
\hline
\end{tabular}




\section{DISCUSSION}

The drainage ditches and improved watercourses, even though commonly found in the Łęczna-Włodawa Lakeland, are not popular objects of floristic or habitat studies. The abovementioned sites have become an element of the landscape and, at the same time, a testimony to anthropopressure which has taken place in the Lakeland since the 1950's, and their importance is considered in hydrological terms. Only few studies prove their importance as the habitats for diverse phytocoenoses and the sanctuaries of the species richness of this area's flora (B a n a c h and $\mathrm{S} \mathrm{zc} \mathrm{zu} \mathrm{row} \mathrm{s} \mathrm{ka,}$ 2007; B a n a ch, 2008; B a n a ch, 2009; P o g o$\mathrm{rze}$ l e c et al. 2009). Due to their specific functioning, associated with the absence of water flow or a very low water flow, as well as on account of the specific structure of their channels formed during the hydraulic improvements, the drainage ditches are unique habitat complexes which create numerous niches for species with different habitat requirements. The vegetation of the drainage ditches functions in the form of unique phytocoenoses which form narrow and long strips. The plant communities interpenetrate, which is the reason for the diversity and variability of the vegetation cover of these habitats (P o d b i e l k o w s k i, 1967). It is not always possible to compare the resources and peculiar characteristics of the flora of an investigated site with other habitats of this type in a particular study area. The character of the habitats of improved watercourses can be confronted with the habitats of drainage ditches due to their anthropogenic nature and a similar way of functioning.

The section of the transformed Piwonia River, functioning as a surrounding ditch of Lake Bikcze, is characterized by great species richness of the flora growing on its slopes and channel. Taking into account the area adjacent to the study site (on one side, the embankment and beyond it the transitional bog, whereas on the other side, fallow meadows and farmland), the multitude of vascular plant species (107 species, which accounts for ca. $6 \%$ of all species of the Lublin region) and their differentiation are very great. In spite of the fact that most of them are taxa common in Poland, certain species whose number of stands has significantly decreased over the last decades (Carex pseudocyperus, C. rostrata, Galium palustre) have also found there favourable conditions for functioning. The occurrence of many plants with medicinal properties have also been recorded there (among others, Rubus ideaus, Achillea millefolium, Plantago major, Hypericum perforatum, Valeriana officinalis; B remness, 1991; I wan i u k, 2006).

According to Urban and R a dwan (2000), on the banks of the lakes, rivers and other water streams of the Łęczna-Włodawa Lakeland, the most frequently developed plant community is the reed bed Phragmition, comprising alliances with the dominant species such as: Schoenoplectus lacustris, Typha angustifolia, Sagittaria sagittifolia, Sparganium erectum, Phragmites australis, Eleocharis palustris, Equisetum fluviatile, Acorus calamus, Glyceria maxima, Oenanthe aquatica and Rorippa amphibia, whereas in the drainage ditches and in other small water streams, there occur communities with a predominance of Glyceria fluitans and Glyceria notata as well as Leersia oryzoides. Święs and Wrzesien (2000) mention that the phytocoenoses with Urtica dioica are exceptionally commonly widespread on the slopes of the old canals and ditches within the Park area.

All the abovementioned taxa, except for Schoenoplectus lacustris, Acorus calamus, Glyceria maxima, Glyceria notata and Leersia oryzoides, were noted in the drainage ditches in the Polesie National Park studied by B a a ch (2009). Common nettle, Urtica dioica, occurred almost at all the 12 study sites, forming more or less dense aggregations mainly on the slopes of the ditches. According to B a n a ch (2008; 2009), the expansion of this species and the location of its population at particular places of the investigated hydrological network can be a consequence of the hydraulic improvements carried out there.

According to U rban and R adwan (2000), the occurrence of only four species characteristic of this type of habitats in the Lakeland was noted in the species composition of the studied section of the surrounding ditch on Lake Bikcze (Typha angustifolia, Phragmites australis, Eleocharis palustris, Equisetum fluviatile). But a numerous population of Urtica dioica was observed on the slopes of the ditch.

The qualitative and quantitative proportions of species belonging to different historical-geographical groups can be used as an indicator of the naturalness of the studied flora (Ch mi e l, 1993a). The study site is a habitat of anthropogenic origin, though man did not have a direct influence on the process of its colonization by the vegetation. Probably that is why spontaneophytes - taxa which arrived or are native to the study area and can exist there without human intervention - had the largest proportion in the flora of the surrounding ditch. Only two species belonged to the group of anthropophytes, that is, species which were introduced or arrived in a given area and persist there only by human activity. The anthropogenic habitats of the surrounding ditch were inhabited by the native flora, characteristic of the study area, and man did not exert a strong pressure on their species composition, which is also evidenced by a low value of the flora anthropophytization index.

According to B a a ch (2009), it is the lack of maintenance of the channels of the ditches, coupled 
with the establishment of the National Park, which decided about the natural character of the flora of the drainage ditches studied by her. A similar correlation was observed during the investigations of the surrounding ditch on Lake Bikcze; this drainage is not regularly cleaned, and the absence of direct human intervention favours the processes of secondary succession of the vegetation on the ditch slopes.

The proportions of groups of different life-forms in the flora of a study area depend directly on climatic factors as well as on the intensity of anthropopressure (Chmiel, 1993a). The analysis of the spectrum of life forms of the flora of the drainage ditch section in question - similarly to the flora of the drainage ditches in the Polesie National Park (B a n a c h, 2009) showed that it was typical of the temperate zone, which was confirmed by the dominant proportion of hemicryptophytes (according to $\mathrm{S} z$ a f e r, 1964, this group accounts for more than a half of the species found in the whole Poland) and a significant proportion of geophytes.

The geographic distribution of species is primarily related to their tolerance to the variability of environmental factors in time and space $(\mathrm{Ch} \mathrm{miel,}$ 1993a). Euro-Siberian and cosmopolitan species were the dominant range elements of the flora of both the surrounding ditch in question and of the drainage ditches in the Polesie National Park (B a n a c h, 2008). A very large proportion of species preferring moderately cool and moderately warm climatic conditions was also noted in the flora of the studied surrounding ditch.

The floristically richest phytocoenoses are those functioning in the heterogeneous environments, since no species has an absolute dominance in them $(\mathrm{Fa}$ $1 \mathrm{i}$ ń s k a, 2004). The slopes and channel of the improved Piwonia River form such a diverse habitat.

The waters of drainage ditches can be quite varied in physico-chemical terms. When studying the drainage ditches in the peat bogs near Warsaw, P o d b i elkowski (1967) divided them, in terms of water $\mathrm{pH}$, into two groups: I. pH 5 to 6; II. pH 6.2 to 9. At the same time, he noticed that the water in the drainage ditches with a pH of more than 6.2 was characterized by a higher content of phosphates and a much higher, even ninefold, concentration of magnesium and calcium. According to $\mathrm{Banach}$ and $\mathrm{Szczurow}-$ s k a (2007), the water in most of the drainage ditches studied in the Eęczna-Włodawa Lakeland had a $\mathrm{pH}$ higher than 6.2, except for the drainage ditches immediately adjacent to the peat bogs. But the authors did not confirm a correlation between $\mathrm{pH}$ and content of ions of the elements mentioned by Podbie $1 \mathrm{kow}$ ski (1967). B an ach and S zczurow ska (2007) found that the higher content of some elements in the waters of the ditches studied by them could have been an effect of the natural processes of decomposition of plant organic compounds or, less frequently, an effect of fertilizer runoff from nearby crop fields. The waters of the Mietiułka River - an improved watercourse flowing through the Polesie National Park - also had a pH higher than 6.0 in different sections of its course. The analysis results of chemical properties of the water samples collected from the Mietiułka watercourse did not also show any clear relationship between $\mathrm{pH}$ and content of ions $\mathrm{Ca}^{2+}$ and $\mathrm{Mg}^{2+}$ (P o g orzele c et al. 2009). The results of the study of ion concentrations of some elements in the water of the Mietiułka River (2006-2007) show that the water sampled from different sites is characterized by their small content. It can be clearly seen that the most fertile habitats are located in the river sections subjected to the greatest human pressure.

The studied section of the surrounding ditch - the transformed Piwonia River, was characterized by the absence of a clear flow of water whose $\mathrm{pH}$ was higher than 6.6. The water was characterized by high electrolytic conductivity, which is evidence of a high content of salts dissolved in the water. The content of organic nitrogen and phosphorus as well as of anions of these elements in the water of the surrounding ditch may indicate the inflow of nutrients from the adjacent crop fields. The analysis of the preferences of the flora species of the ditch in relation to the trophic state of the habitat indicates a nutrient-rich substrate - eutrophic, and a moderately poor substrate - mesotrophic, whereas the large percentage proportion of species characteristic of mineral/humic soils and organogenic soils allows us to infer that the substrate is highly rich in organic matter.

In spite of the anthropogenic nature of the investigated watercourse, it is a habitat of diverse flora, characteristic of the Łęczna-Włodawa Lakeland region.

\section{REFERENCES}

B a n a h B. 2008. Rare and protected species in the drainage ditches and adjacent phytocoenoses in the Polesie National Park. Acta Agrobot. 61 (2): 103-111.

B a n a h B. 2009. Vascular flora of drainage ditches in forest area of the Polesie National Park. Acta Agrobot. 62 (1): 117-126.

Banach B., Szczurowska A. 2007. Chemical characterization of water from selected melioration ditches with different habitats (Poleski National Park). Polish J. Environ. Stud. 16 (2A): 57-61.

Bremness L. 1991. The complete book of herbs. Wiedza i Życie. Warszawa.

Chmiel J. 1993 a. Flora roślin naczyniowych wschodniej części Pojezierza Gnieźnieńskiego i jej antropogeniczne przeobrażenia w wieku XIX i XX. Część I. Atlas rozmieszczenia roślin. Sorus, Poznań. 
Chmiel J. 1993 b. Flora roślin naczyniowych wschodniej części Pojezierza Gnieźnieńskiego i jej antropogeniczne przeobrażenia w wieku XIX i XX. Część II. Atlas rozmieszczenia roślin. Sorus, Poznań.

Falińska K. 2004. Ekologia roślin. Państwowe Wydawnictwo Naukowe, Warszawa.

Fijałk owski D. 1976. Land of the lakes and bogs. Przyroda Polska, 11: 9. (in Polish).

Furtak T., Sobolewski W., Turczyński M. 1998. Charakterystyka zlewni jezior. [In]: M. Harasimiuk, Z. Michalczyk, M. Turczyński (eds). Jeziora łęczyńskowłodawskie. Monografia przyrodnicza: 73-90, Biblioteka Monitoringu Środowiska, Lublin.

Harasimiuk M., Wojtanowicz J. 1998. Budowa geologiczna i rzeźba terenu Pojezierza Łęczyńsko-Włodawskiego. [In:] M. Harasimiuk, Z. Michalczyk., M. Turczyński (eds), Jeziora łęczyńsko-włodawskie. Monografia przyrodnicza: 45-48, Biblioteka Monitoringu Środowiska, Lublin.

Iw a n iu k A. 2006. Atlas ziół krajowych. Wydawnictwo Bellona. Warszawa.

Jack owiak B . 1990. Antropogeniczne przemiany flory roślin naczyniowych Poznania. Ser. Biologia 42. Wydawnictwo Naukowe UAM, Poznań.

Lorens B., Grądziel T., Sugier P. 1998. Zmiany roślinności w ekotonie woda-ląd jeziora Bikcze w latach 1993-1998. [In:] S. Radwan (ed.), Ekotony słodkowodne - struktura - rodzaje - funkcjonowanie: 51-63, Wydawnictwo UMCS, Lublin, 51-63.

Michalczyk Z., Turczyński M. 1998. Przekształcenia i zagrożenia hydrosfery. [In:] M. Harasimiuk, Z. Michalczyk., M. Turczyński (eds), Jeziora łęczyńsko-włodawskie. Monografia przyrodnicza: 157-164, Biblioteka Monitoringu Środowiska, Lublin.

Mirek Z., Piękoś-Mirkowa H., Zając A., Zając M. 2002. Flowering Plants and Pteridophytes of Poland. A Checklist. W. Szafer Institute of Botany, Polish Academy of Science, Kraków.

Podbielkowski Z. 1967. Overgrowing of drainage ditches in peat bogs in the Warsaw area. Monographiae Botanicae, Warszawa, 23 (1): 19-24 (in Polish).

Pogorzelec M., Banach B. 2008. The occurrence of rare and protected plant species in the peat bog on Lake Bikcze (Łęczna-Włodawa Lakeland). Acta Agrobot. 61 (2): 113-120.

Pogorzelec M., Czernaś K., Stelmach Ł., Szadkowski P. 2009. Habitat differentiation of the Mietiułka River in relation to changes in its route and in land use within its catchment. Teka Kom. Ochr. Kszt. Środ. Przyr. OL PAN, 5: 242-251.

Report upon natural environment of Lublin region in 2007. 2008. Library of Environmental Monitoring, Lublin, (in Polish).

Rutkowski B. 2001. Klucz do oznaczania roślin naczyniowych Polski niżowej. Państwowe Wydawnictwo Naukowe, Warszawa.
Serafin A., Czernaś K. 2009. Phytoplankton productivity in littoral of selected lakes in Łęczna-Włodawa Lakeland in summer 2007-2008. Teka Kom. Ochr. Kszt. Środ. Przyr. OL PAN, 6: 311-319.

S z a fe r W. 1964. Ogólna geografia roślin. Państwowe Wydawnictwo Naukowe, Warszawa.

Święs F., Wrzesień M. 2000. Ekosystemy synantropijne w Poleskim Parku Narodowym. [In:] S. Radwan, Z. Lorkiewicz (eds), Problemy ochrony i użytkowania obszarów wiejskich o dużych walorach przyrodniczych. 263-277 Wydawnictwo UMCS, Lublin (in Polish).

Turczyński M., Michalczyk Z., Bartoszewski S. 2000. Geograficzne aspekty ochrony i użytkowania hydrosfery Pojezierza Łęczyńsko-Włodawskiego. Lakeland. [In:] S. Radwan, Z. Lorkiewicz (eds). Problemy ochrony i użytkowania obszarów wiejskich o dużych walorach przyrodniczych: 57-61, Wyd. UMCS, Lublin.

Urban D., Radwan S. 2000. Ekosystemy torfowiskowe. [In:] T. J. Chmielewski (ed.), Międzynarodowy Rezerwat Biosfery „Polesie Zachodnie”: 43-45, PPN, Lublin.

Wilgat T. 1991. Stosunki wodne Pojezierza ŁęczyńskoWłodawskiego. Zmiany stosunków wodnych pod wpływem gospodarki [In:] A. S. Kleczkowski (ed.). Studia Ośrodka Dokumentacji Fizjograficznej PAN, Wrocław, Warszawa, Kraków, 19: 48-52 (in Polish).

Wojciechowski I. 1976. Influence of a catchment on eutrophication of a-mesotrophic Piaseczno lake and deeutrophication of a pond-type Bikcze lake. Acta Hydr. 18, (1): 23-52, Kraków, (in Polish).

Wojciechowski I., Wojciechowska W., Czernaś K., Galek J., Religa K. 1988. Changes in phytoplankton over a ten-year period in lake undergoing de-eutrophication due to surrounding peat bogs. Arch. Hydrobiol. Suppl. 78(3): 373-387 (Algological Studies 48), Stuttgart.

Zarzycki K., Trzcińska-Tacik H., Różański W., Szeląg Z., Wołek J., Korzeniak U. 2002. Ecological Indicator Values of Vascular Plants of Poland. Ekologiczne liczby wskaźnikowe roślin naczyniowych Polski. W. Szafer Institute of Botany, Polish Academy of Science, Kraków.

\section{Flora naczyniowa fragmentu przekształconego koryta rzeki Piwonii - rowu opaskowego nad jeziorem Bikcze (Pojezierze Łęczyńsko-Włodawskie), na tle warunków siedliskowych}

\section{Streszczenie}

W latach 2007-2009 dokonano analizy florystycznej, siedliskowej i fizyczno-chemicznej rowu opaskowego przebudowanego hydrotechnicznie jeziora Bikcze na Pojezierzu Łęczyńsko-Włodawskim. Głównym komponentem flory badanego odcinka 
przekształconego koryta rzeki Piwonii były hemikryptofity ze znacznym udziałem geofitów oraz hydrofitów i helofitów. W przypadku klasyfikacji historycznogeograficznej dominowały spontaneofity, a wśród nich apofity, natomiast antropofity były miernie reprezentowane, co potwierdziły odpowiednio wysokie wartości wskaźników synantropizacji i apofityzacji (>50\%) oraz niska wartość wskaźnika antropofityzacji (ok. $2 \%$ ). W aspekcie zasięgu występowania dominowały gatunki eurosyberyjskie i kosmopolityczne, klasyfikowane pod względem liczb wskaźnikowych jako rośliny wilgociolubne, neutralne wobec kontynentalizmu, żyjące w umiarkowanie chłodnych lub umiarkowanie ciepłych warunkach klimatycznych, cechujące się szerokim spektrum tolerancji wobec wskaźnika trofii oraz wskaźnika kwasowości gleby. Analiza wartości podstawowych czynników fizyczno-chemicznych wody stagnującej w rowie opaskowym wskazała na wahania wartości odczynu, przewodności elektrolitycznej oraz wartości stężenia azotu organicznego i amonowego, a także fosforu organicznego i fosforanów. Pomimo antropogenicznego charakteru badanego cieku wodnego jakościowy i ilościowy udział gatunków flory wskazywał na jej naturalny stan oparty na rodzimej roślinności, charakterystycznej dla terenu badań. 
